\title{
Pre-IPO Accrual Quality and Under-pricing in the Indonesian Market
}

\author{
Yanthi Hutagaol-Martowidjojo ${ }^{1 *}$, Mookung Kim²
}

\author{
${ }^{1,2}$ Bina Nusantara University \\ *Corresponding author.Email: yhutagaol@binus.edu
}

\begin{abstract}
This study investigates the relationship between pre-IPO firms' earnings quality that is proxied by accrual quality (AQ) prior to the IPO, and their underpricing degree in their early days of trading. Our main argument is that pre-IPO AQ is one source of information risk that affect the degree of information asymmetry among the issuing firms and potential investors. By the measurement, the higher AQ reflects lower quality of accrual. Using the regression models on a sample of 144 Indonesian IPO firms that went public during 2007-2017, this study finds that there is a positive relationship between the AQ and the underpricing degree. It implies that the higher the AQ (lower quality of accrual) of a firm, the higher the underpricing degree will be. In other words, the better the AQ of a firm, the lower the firm's information asymmetry will be in the market, resulting in a lower underpricing degree in the early trading days. Furthermore, our study extends and includes some control variables, namely market condition, public ownership, and underwriter reputation. The managerial implication of this study is that as firms prepare to go public it is important for the managers of firms to maintain a good accrual quality in order to decrease the market information asymmetry of their offerings.
\end{abstract}

Keywords: Accrual Quality, Information Asymmetry, IPO, Under-Pricing

\section{INTRODUCTION}

The performance of IPO shares in their early trading days has been extensively studied over the years. Most IPOs around the world would have higher prices on the first to the fifth days of trading, and it is well documented as an underpricing phenomenon [1]. The IPO underpricing happens in all markets globally [2] while in developing countries it is higher than developed markets [3]. For the last 10 years, the underpricing degree of Indonesian IPO market (Indonesian Stock Exchange, IDX) is shown in Table I.

Table 1. Number of IPO and Underpricing in IDX in 20072017

\begin{tabular}{|c|c|c|c|}
\hline Year & $\begin{array}{c}\text { Number of IPO } \\
\text { firms }\end{array}$ & underpriced & Percentage \\
\hline 2007 & 22 & 21 & 95.4 \\
\hline 2008 & 19 & 16 & 84.2 \\
\hline 2009 & 12 & 8 & 66.6 \\
\hline 2010 & 23 & 22 & 95.6 \\
\hline 2011 & 26 & 17 & 65.3 \\
\hline
\end{tabular}

\begin{tabular}{|c|c|c|c|}
\hline Year & $\begin{array}{c}\text { Number of IPO } \\
\text { firms }\end{array}$ & underpriced & Percentage \\
\hline 2012 & 22 & 21 & 95.4 \\
\hline 2013 & 30 & 22 & 73.3 \\
\hline 2014 & 24 & 20 & 83.3 \\
\hline 2015 & 16 & 16 & 100 \\
\hline 2016 & 15 & 14 & 93.3 \\
\hline 2017 & 37 & 34 & 91.8 \\
\hline average & 22.4 & 19.1 & 85.8 \\
\hline
\end{tabular}

Source: Market Data from Indonesian Stock Exchange. PT Bursa Efek Indonesia www.idx.co.id

There has been a vast amount of literature discussing the determinants of IPO underpricing. One determinant is accounting information. The research examining the relationship of accounting and IPO prices started in the early 2000s $[4,5,6]$. Those studies provide evidence of the important role of accounting information on the IPO pricing process. The subsequent studies in the area developed into more specific aspects of accounting information, in particular a firm's net incomes (earnings) such as earnings management [7], forecasted earnings [8-10] among others. 
Teoh et al. [7] examined pre-IPO earnings management and the long-run performance of IPO stocks in the US. They concluded that firms which implemented earnings management prior to their IPOs would experience worse stock returns in the three years after initially trading in the market. Moreover, they also found a negative relationship between underpricing degree and long-run performance of the research sample firm's stocks. The earnings management incidences show low quality of earnings figures reported by the firms. The examination of earnings quality (EQ) has been conducted extensively in developed and emerging markets [11-13]. In relation with IPO, Ball and Shivakumar [14] analyzed firms' EQ at the IPO. They found that IPO firms are more conservative in reporting their earnings, which implies that their earnings quality is better than that of private firms. Using the Demand Theory, Hutagaol Martowidjojo and Widyanto [15] reported that there is an increasing EQ in terms of accrual quality and earnings predictability after firms become public firms. Moreover, Boulton, Smart and Zutter [16] show that underpricing degree is lesser in countries where IPO firms report higher EQ.

The relationship between Indonesian established firms' EQ and their market valuation in Indonesia was studied by Hutagaol-Martowidjojo, Valentinčič, and Warganegara [14]. However, no study has examined Indonesian IPO firms' EQ and its relationship with IPO pricing. This study aims to examine pre-IPO EQ and underpricing in the Indonesian market. This study contributes to the IPO research area in two ways. Firstly, it expands upon the study by HutagaolMartowidjojo and Widyanto [17] by testing the impact of pre-IPO EQ, specifically accrual quality on IPO pricing during the early days of trading and secondly, it extends Boulton et al. [16] study by providing evidence on EQ and underpricing at the firm level.

The results of this study show that pre-IPO accruals quality (AQ) is positively related to underpricing degree for Indonesian firms. It implies that firms reporting higher preIPO AQ (lower quality of accruals) experience higher underpricing degree. It is argued that higher pre-IPO accrual quality increases information asymmetry between firms and potential investors, which leads to a more diverged pricing process and, in turn, lower underpricing.

The paper is structured as follows. The next section is a related literature review and hypothesis development; the following sections are methodology, results and discussion, and conclusion.

\section{LITERATURE REVIEW}

Accounting accruals have gained attention in academia as an important indicator of earnings quality that is useful for valuation [18]. Accrual quality is one of the attributes of the quality of accounting information and is defined as the uncertainty associated with the accrual to cash flow [19]. In addition, Teoh and Wong, [20] found that "accruals contain important information for the future earnings of the firm". However, this information is certainly not available to investors; hence, the valuation affecting reported earnings at the time of reporting has not appeared. It is especially in the interests of investors and managers during the IPO in the capital market. Since there are lots of variables influencing the accruals quality FLOS [21] argue that accruals quality is an important source of non-diversifiable "information risk" [22].

In addition, previous research has shown that higher levels of information asymmetry can lead to adverse selection and moral hazard [23] Since the potential investors do not have enough information and knowledge about the IPO offering stock price, the firms going public are tempted to commit underpricing to attract investors. The firms that have a higher degree of information asymmetry to uninformed investors tend to have a higher degree of accrualbased manipulations [24].

Underpricing provides outside investors high returns and thus builds underwriters' reputation [25]. Most of the previous research showed that the significant levels of negative effect of the underwriter's reputation were found in the IPO. Several studies found that third parties, such as auditors and issuing underwriters are involved in the IPO process and if it is reputable IPO [26]. Therefore, an underwriter's reputation is negatively associated with earnings management [27].

Dechow and Dichev's [28] model is commonly used in accruals and earnings management studies. The model posits a relation between the current period working capital accruals and operating cash flows in the prior, current and future periods. In this study we applied the Dechow-Dichev (DD) model as one proxy for measuring the relationship between accrual quality and the degree of underpricing. Prior research also found that the accrual may be reversed later leading to poor post-IPO performance. Teoh, Welch, and Wong [29] find strong evidence supporting this conjecture.

Overall, a higher accruals quality gives investors better knowledge and information of the value of issuing firms. The information asymmetry between issuers and investors and between informed investors and uninformed investors can be lessened [30]. Therefore, we can predict that the magnitude of $\mathrm{AQ}$ increases the degree of underpricing firms in Indonesia.

In summary, even though there has been extensive research on accrual earning management and underpricing, only limited studies were conducted to investigate the relationship between pre-IPO accrual quality and underpricing degree. This study also examines the relationship between following variables - public ownership, underwriter reputation, market condition, and underpricing degree. 


\section{METHODS}

The sample of this study was drawn from all the firms that went public in the country's stock exchange, which was a primary equity market during the ten-year period from 2007 2017. The accounting data was manually collected from the offering prospectuses and the stock price data was collected from Yahoo! Finance. Two criteria were applied to select the sample. Firstly, the IPO firms were not in the financial sector; secondly, the IPO prospectuses were in IDR currency. We excluded 102 firms from an initial 246 samples. The final sample derivation was presented in the following table 2:

Table 2. Sample Derivation

\begin{tabular}{|l|r|r|}
\hline \multicolumn{1}{|c|}{ Sample } & & Total \\
\hline Population of IPOs 2007-2017 & & 246 \\
\hline Excluded & & \\
\hline Banking and Financial firms & $(36)$ & \\
\hline Foreign currency prospectus & $(28)$ & \\
\hline Missing Data & $(38)$ & \\
\hline Final Sample & & 144 \\
\hline
\end{tabular}

The main variables in this study are underpricing degree (UP) and pre-IPO Accrual Quality (AQ). To estimate the AQ, this study employs the Dechow-Dichev (DD) model. The model is expressed as follows.

$$
\Delta W C_{i, t}=\varphi_{0}+\varphi_{1} * C F O_{i, t-1}+\varphi_{2} * C F O_{i, t}+\varphi_{3} * C F O_{t+1}+v_{i, t}
$$

Where, $\Delta \mathrm{WCi}, \mathrm{t}=$ changes in working capital, calculated as $=\Delta A / R+$ Inventory $-\Delta A / P-\Delta T / P+\Delta$ other non-cash current assets (net); and $C F O_{i, t}=$ operating cash flows in year $t$; $t$ is the base year that is one year before IPO year.. PreIPO AQ is proxied by $v_{i, t}$ that is the residual of DD model in equation (1)

Meanwhile, the UP is calculated by the relative difference between the market price in the first trading day and the offer price, as expressed in equation (2)

$$
\mathrm{UP} i=\left(P_{1 i}-P_{0 i}\right) / P_{0 i}
$$

Where, $U P_{i}$ is underpricing degree of firm i; $P_{l i}$ is the closing market price of firm i on the $1^{\text {st }}$ trading day; $P_{0}$ is the offer price of firm i. (3)To test the relationship between pre-IPO AQ and UP, some control variables are included in the research model that will be analyzed using the multivariate OLS regression analysis. The research model used is expressed as follow.

$$
\begin{aligned}
& U P_{i}=\delta_{0}+\delta_{1} A Q_{i}+\delta_{2} P u b O w n_{i}+\delta_{3} U W_{i}+ \\
& \delta_{4} \text { Market }_{i}+\varepsilon_{i}
\end{aligned}
$$

Where, PubOwni is the percentage of shares sold to public at IPO $i$; UW $i$ is the reputation of underwriter of IPO $\mathrm{i}$ is a dummy variable that takes a value of 1 if the underwriter is categorized as one of the top 10 underwriters in IDX, based on the total value of listed equity and debt instruments that are underwritten in the corresponding year, and a value of 0 , otherwise; Market $i$ is a dummy variable, that takes a value of 1 on the year when number of IPOs are greater than median, and a value of 0 , otherwise.

\section{RESULTS AND DISCUSSIONS}

This section presents and discusses this study results, starting with the sample descriptive statistics analysis

Table 3. Descriptive Statistics of IPO Firms During 20072017

\begin{tabular}{|c|c|c|c|c|c|}
\hline Variable & Mean & Median & $\begin{array}{c}\text { Std } \\
\text { Dev }\end{array}$ & Min & Max \\
\hline UP & 0.5703 & 0.5837 & 0.6519 & -1.3637 & 2.4007 \\
\hline AQ & 0.0662 & 0.0671 & 0.0258 & 0.0004 & 0.1635 \\
\hline PubOwn & 0.2456 & 0.2303 & 0.0999 & 0.1 & 0.4737 \\
\hline UW & - & 1 & 0.5015 & 0 & 1 \\
\hline Market & - & 1 & 0.4423 & 0 & 1 \\
\hline
\end{tabular}

Table 3 above summarize the medians, means, SDs, and ranges of variables of underpricing, accruals quality, public ownership, underwriters' reputation and market condition of a sample of 144 Indonesian IPO firms from 2007 to 2017. Underpricing is returns differences calculated from a firm's closing price on the first day of IPO divided by the offering price with a mean value of 57 percent and a median value of 58 percent respectively. The range of underpricing varies greatly from 136 percent to 240 percent. This shows that there were several IPOs that did not experience underpricing. In the research sample, about $14 \%$ of IPOs were not underpriced. Accrual quality of the IPO firms studied here showed average 0.0662 and median 0.0671 . Since the mean and median are positive, they indicate that the sample IPO firms tended to attempt accrual management via working capital prior to their IPOs. Public ownership shows the sample IPOs on average sold the shares to public according to the IDX regulation (25\%). Most of the research sample is underwritten by lead underwriters that are listed in the top 10 underwriters in IDX.

The summary of statistics for research variables for this study are presented in Table IV below. The UP and AQ relationship is positive and significant, indicating the expected effect of AQ on UP. A similar indication is shown by the negative coefficient of correlation between UP and UP, implying that IPOs that were underwritten by reputable underwriters experienced lower underpricing. Meanwhile, insignificant correlations are found for UP and PubOwn, and Market, respectively. There is no high correlation among the independent variables. It assures that there is no multicollinearity problem in the research data. 
Table 4. Pearson Correlation Analysis

\begin{tabular}{|c|r|r|r|r|r|}
\hline & UP & AQ & PubOwn & UW & Market \\
\hline UP & 1 & & & & \\
\hline AQ & $0.5387^{* * *}$ & 1 & & & \\
\hline PubOwn & 0.1336 & 0.0705 & -0.0270 & 1 & \\
\hline UW & $-0.4776^{* * *}$ & -0.0800 & -0.1013 & 0.0166 & Notes: *** significant at $\alpha=0.01$ \\
\hline Market & -0.0513 & 0.0833 & & & \\
\hline
\end{tabular}

The main analysis of this study is shown in Table 4 below. The result is presented in two columns. The second column of Table $\mathrm{V}$ presents the regression analysis of the main variables, UP and AQ. The third column of the table presents the regression analysis with the inclusion of the control variables.

The positive constants of both analyses confirm prior studies of IPO underpricing fact. Both coefficients representing the average UP of research sample. Positive coefficients show that on average the sample IPOs are underpriced.

Table 5. Regression Analysis

\begin{tabular}{|c|c|c|}
\hline $\begin{array}{c}(1) \\
\text { Variable }\end{array}$ & UP & $(3)$ \\
\hline \multirow{2}{*}{ Constant } & $0.3307^{* * *}$ & $0.4204^{* *}$ \\
& $(-2.6079)$ & $(-2.1767)$ \\
\hline \multirow{2}{*}{$A Q$} & $13.5956^{* * *}$ & $13.7251^{* * *}$ \\
& $(7.6200)$ & $(7.6384)$ \\
\hline \multirow{2}{*}{ PubOwn } & - & 0.0056 \\
& - & $(1.2234)$ \\
\hline \multirow{2}{*}{ UW } & & $-0.2502^{*}$ \\
& - & $(-1.9400)$ \\
\hline \multirow{2}{*}{ Market } & & -0.13102 \\
& & $(-0.1249)$ \\
\hline Adj R-Square & 0.2852 & 0.2894 \\
\hline F-stat & $58.0650^{* * *}$ & $15.5581^{* * *}$ \\
\hline
\end{tabular}

Notes: $* * *$ significant at $\alpha=0.01 ; * *$ significant at $\alpha=0.05 ; *$ significant at $\alpha=0.10$

As shown in the second column, the AQ coefficient is positive. After controlling for the effect of other variables column 3, the AQ retains a positive sign, implying that the greater the AQ (lower accrual quality) the higher the UP. The result is as expected as this study hypothesizes that the lower accrual quality leads to higher information asymmetry as measured by the underpricing degree.

As argued by FLOS [18] this study shows that accrual quality can be perceived as a source of non-diversifiable "information risk" [19] that leads to information asymmetry among participants in IPO market as reflected by the underpricing [27]. Furthermore, this result also provides evidence that support Boulton et al. [13] at firm level. Firms that reported lower accrual quality prior to their IPO experience higher underpricing.

Besides the significance of AQ coefficients, the AQ coefficient magnitude is also high (13.5956), even after the model is controlled by another variable (13.7251). The dominant effect of AQ on UP is also shown by the trivial increase in the adjusted square of the model. The small increase is contributed by the effect of the UW, as discussed in the next paragraph.

Column 3 presents the negative coefficient of UW. It implies that IPOs that were brought to the market by reputable underwriters did show lower UP. As discussed by Loughran and Ritter [2], firms hire reputable underwriters to increase the analyst coverage of the firm since the activities of reputable underwriters are mostly followed by market analysts. From the investors' (market) point of view, this study argues that underwrites put their reputation at stake when they underwrite IPOs; therefore, underwriters may have the motive to choose good firms to underwrite, including firms that have good quality of financial reports. Based on those arguments, the IPO will be less underpriced when it is underwritten by a reputable underwriter. This result helps to confirm the prior studies [16], [31].

The analysis of the full model (see column 3) fails to provide a significant effect of PubOwn and Market on UP. This can be attributable to a low percentage of shared offered to public, compared to other markets, relatively. As a comparison, in the developed market, such as UK, firms have to offer more than $50 \%$ of their outstanding shares to fulfill the requirement to be listed in the London Stock Exchange. Therefore, it can be said that public has insignificant power to influence the market, in particular the IPO pricing.

Although the period in this study is long enough to observe the IPO market condition (hot and cold markets), the result fails to show its significant effect on the underpricing. This result cannot support the results of Helwege and Niang [32] and Rathnayake et al. [33]. However, Helwege and Niang [32] concluded that hot and cold IPO markets had an insignificant difference in the characteristics of the firm as well as the quantity of firms that go public. This implied that the test of hot and cold market should be dropped in favor of another measurement such as the number of firms going public in the corresponding year. 


\section{CONCLUSION}

This study aims to investigate the effect of accrual quality on the underpricing degree in the Indonesian IPO market from 2007 to 2017. This study finds evidence to support the hypothesis that state firms with higher accrual quality prior to their IPOs experience lower underpricing degree. It can be concluded that accrual quality is one element of information risks leading to information asymmetry that is reflected in the underpricing degree. This shows that the quality of pre-IPO financial statements matters. Firms that plan to go public should prepare their financial statements well before the event.

In this paper, we also highlight the importance of the underwriter in the IPO pricing in the early trading days. It is found that IPOs that hire reputable underwriters experience lower underpricing degree as argued from two perspectives - that of the issuing firms and that of the underwriter. The issuing firms prefer underwriter-affiliated forecast, thus hire the more reputable underwriters to get higher analyst coverage, resulting in attracting potential investors. Meanwhile, it is in the underwriters' interests to choose good firms to underwrite.

However, this study cannot provide evidence for the effect of public ownership and market condition on the IPO underpricing degree. It is argued in this study that public investors in Indonesia are in a weak position to influence the pricing process in the IPO market. Therefore, it is suggested that different measurements for a firm's ownership structure be employed. A similar suggestion is also applied to market conditions. Based on Helwege and Niang [32], the IPO hot and cold markets should be proxied by other aspects besides the number of firms going public in issue-year.

\section{REFERENCES}

[1] P. Engelen, M.V. Essen, Underpricing of IPOs: Firmissue and country-specific characteristics, Journal of Banking \& Finance, United States: Elsevier Science, vol. 34, 2010, pp. 1958-1969.

[2] T. Loughran, J.R. Ritter, K.Rydqvist, Initial public offerings: International insights, Pacific-Basin Finance Journal, Australia: Elsevier Science, vol. 2, 1994, pp. 165-199.

[3] S. Venkatesh, S. Neupane, Does ownership structure affect IPO underpricing: Evidence from Thai IPOs, School of Management, Asian Institute of Technology, Bangkok, Thailand, 2005.

[4] M. Kim, J.R. Ritter, Valuing IPOs, Journal of Financial Economics, Unoted States: Elsevier Science, vol. 53, 1999, pp. 409-437.

[5] R. Beatty, S. Riffe, R. Thompson, IPO Pricing with Accounting Information, Southern Methodist University, April 2000.

[6] G. Chen, M. Firth, G.V. Krishnan, Earnings forecast errors in IPO prospectuses and their association with initial stock returns, Journal of Multinational Financial
Management, Hungary: Elsevier Science, vol 11(2), 2001, pp 225-240.

[7] S.H. Teoh, I. Welch, T. Wong, Earnings Management and the Long-Run Market Performance of Initial Public Offerings, The Journal of Finance, Wiley for the American Finance Association, vol. 53, 1998, pp. 19351974.

[8] V. Jog, B.J. McConomy, Voluntary disclosure of management earnings forecasts in IPO prospectuses, Journal of Business Finance \& Accounting, UK \& USA : Blackwell Publishing ltd, vol. 30, 2003, pp. 125-168.

[9] K. Nagata, Does earnings management lead to favorable IPO price formation further underpricing? Evidence from Japan, Journal of Multinational Financial Management, Hungary: Elsevier Science, vol. 23, 2013, pp. 301-313.

[10] J. Bedard, D. Coulombe, L.Courteau. The credibility of earnings forecasts in IPO prospectuses and Underpricing, Accounting Perspectives, Wiley for CAAA, vol. 15, 2016, pp. 235-267.

[11] J. Francis, R. LaFond, P.M. Olsson, K. Schipper, Cost of equity and earnings attribute, The Accounting Review, US: American Accounting Association, vol. 79, 2004, pp. 967-1010.

[12] I. D. Dichev, J.R. Graham, C.R. Harvey, S. Rajgopal, Earnings quality: evidence from the field, Journal of Accounting and Economics, United States: Elsevier Science, vol. 56, 2013, pp. 1-33.

[13] C. Gaio, C. Raposo, Earnings quality and firm valuation: International evidence, Accounting \& Finance, Australia \& New Zealand: Wiley, vol. 51, 2011, pp. 467-499.

[14] R. Ball, L. Shivakumar, Earnings quality at initial public offerings, Journal of Accounting and Economics, Unnited States: Elsevier Science, vol. 45, 2008, pp. 324-349.

[15] Y.M Hutagaol, F. Widyanto, Earnings quality of Indonesian firms surrounding initial public offerings, International Journal of Accounting, Auditing and Performance Evaluation, Switzerland: Inderscience Publishers, vol. 14, 2018, pp. 47-62.

[16] T.J. Boulton, S.B. Smart, C.J. Zutter, Earnings quality and international IPO underpricing, The Accounting Review, US: American Accounting Association, vol. 86, 2011, pp. 483-505.

[17] Y.M. Hutagaol, A.Valentincic, D.L. Warganegara, Earnings Quality and Market Values of Indonesian Listed Firms, Australian Accounting Review, Australia: Wiley, vol. 29, 2019, pp. 95-111.

[18] K. Chan, L.K. Chan, N. Jegadeesh, J. Lakonishok. Earnings quality and stock returns, National bureau of economic research No. w 8308, 2001.

[19] N. Bhattacharya, H. Desai, K. Venkataraman, Does earnings quality affect information asymmetry? Evidence from trading costs, Contemporary Accounting Research, Canada: Wiley, vol. 30, 2013, pp. 482-516. 
[20] S.H. Teoh, T.J. Wong, Why new issues and highaccrual firms underperform: The role of analysts' credulity, The Review of Financial Studies, US: Oxford University Press, vol. 15, 2002, pp. 869-900.

[21] J. Francis, R. LaFond, P.M. Olsson, K. Schipper, The market pricing of accruals quality, Journal of Accounting and Economics, United States: Elsevier Science, vol. 39, 2004, pp. 295-327.

[22] D. Easley, M. O'hara, Information and the cost of capital, The journal of finance, Wiley for the American Finance Association, vol. 59(4), 2004, pp. 1553-1583.

[23] J. Johnston, J. Madura, The pricing of IPOs postsarbanes-oxley, Financial Review, United States: Wiley, vol. 44(2), 2009, pp. 291-310.

[24] R. Michaely, W.H. Shaw, The pricing of initial public offerings: Tests of adverse-selection and signaling theories, The Review of Financial Studies, United States: Oxford Unoversity press, vol. 7(2), 1994, pp. 279-319.

[25] J.C. Brau, P.M. Johnson, Earnings management in IPOs: Post-engagement third-party mitigation or issuer signaling?, Advances in Accounting, United States: Elsevier Science, vol. 25(2), 2009, pp. 125-135.

[26] J.R. Ritter, I. Welch, A review of IPO activity, pricing, and allocations, The journal of Finance, United States: Wiley, vol. 57(4), 2002, pp. 1795-1828.
[27] V.J. Richardson, Information asymmetry and earnings management: Some evidence,.Review of quantitative finance and accounting, United States: Springer, vol. 15(4), 2000, pp. 325-347.

[28] P.M. Dechow, Dichev, I. D, The quality of accruals and earnings: The role of accrual estimation errors, The accounting review, United States: American Accounting Association, vol. 77(s-1), 2002, pp. 35-59.

[29] S.H. Teoh, I. Welch, T.J. Wong, Earnings management and the long-run market performance of initial public offerings, The journal of finance, United States: Wiley, vol. 53(6), 1998, pp. 1935-1974.

[30] S. Xu, G. Gong, X. Gong, Accruals quality, underwriter reputation, and corporate bond underpricing: Evidence from China, China Journal of Accounting Research, China: Elsevier Science, vol. 10(4), 2017, pp. 317-339.

[31] T. Loughran, J. Ritter, Why has IPO underpricing changed over time?, Financial management, Hong Kong: Wiley, vol. 5-37, 2004.

[32] J. Helwege, N. Liang, Initial Public Offerings in Hot and Cold Market, Journal of Financial Quantitative Analysis, vol. 38, 2004, pp. 541 -569.

[33] D. N. Rathnayake, P.A. Louembe, D.F. Kassi, G.Sun, D. Nng, Are IPOs underpriced or overpriced? Evidence from an emerging market, Research in International Business and Finance, United States: Elsevier Science,vol. 50, 2019, pp. 171-190. 